\title{
ESTABLISHING THE UNCONSTITUTIONALITY OF MENSTRUAL EXCLUSION PRACTICES IN INDIA
}

\author{
DIVYA SRINIVASAN \& BHARTI KANNAN*
}

\section{INTRODUCTION}

Socio-cultural norms, stigmas, and taboos associated with menstruation in India take a number of different forms, often resulting in severe restrictions on menstruators, which are described in Part II, below. In fact, a 2016 study found that only one in eight adolescent girls in India faced no restrictions at all during menstruation. ${ }^{1}$ The constitutionality of menstrual exclusion practices has most famously been challenged in the Sabarimala case, where the Indian Supreme Court in a 4:1 majority found that the law restricting entry of women of menstruating age into the Sabarimala temple violated women's constitutional rights to religion and equality. In Part III, analyzing the judgment in Sabarimala, this Article will explore the potential of applying the verdict in Sabarimala to raise constitutional challenges to other forms of menstrual exclusion practices in the country.

\section{Scope of Menstrual Exclusion}

Menstrual exclusion largely refers to those practices that restrict, inhibit, and limit menstruators' agency to participate in everyday life. This could potentially have consequences that range from mild to severe psychosocial distress and trauma, to violations that manifest differently in spaces of home, places of worship, schools, and workplaces. As acknowledged by a group of United Nations Human Rights Experts:

\footnotetext{
* Divya Srinivasan is a human rights lawyer, with a background in research, policy and advocacy. Her work focuses on issues relating to human rights, particularly gender, and digital rights. She has obtained her LL.M. with a concentration in International Human Rights from Harvard Law School.

Bharti Kannan is founder at Boondh, a hybrid social enterprise that works in the space of menstrual literacy, policy, advocacy, activism and sustainable products. She holds a Masters in Disaster Management from the Tata Institute of Social Sciences, Mumbai, with specialization in gender, public health and conflict studies. Her work includes expanding the theme of advocacy and interventions on Menstrual Discrimination in India. Currently she is one among the four inaugural co-chairs of the Sub Working Group on Adolescent Sexual and Reproductive Health
}

${ }^{1}$ Anna Maria van Eijk et al., Menstrual Hygiene Management Among Adolescent Girls in India: A Systematic Review and Metanalysis, 6 BMJ OPEN 1, 8 (2016). 
The stigma and shame generated by stereotypes around menstruation have severe impacts on all aspects of women's and girls' human rights, including their human rights to equality, health, housing, water, sanitation, education, freedom of religion or belief, safe and healthy working conditions, and to take part in cultural life and public life without discrimination. ${ }^{2}$

As part of a campaign to \#StopPeriodPenalty in India, Boondh undertook an online survey between November 2020 and March 2021 to build evidence on the various forms of menstrual discrimination. The survey ${ }^{3}$ (unpublished), currently with 1,543 respondents, confirmed the top places of occurrence of such practices are homes/private space $(67 \%)$, places of worship (63\%), followed by schools $(28 \%)$, workplaces $(15 \%)$, public places (5\%), and medical institutions (3\%).

\begin{tabular}{|l|l|l|l|l|l||}
\hline $\begin{array}{l}\text { Place/ } \\
\text { Type }\end{array}$ & $\begin{array}{l}\text { Places } \\
\text { of } \\
\text { Worship }\end{array}$ & $\begin{array}{l}\text { Homes/ } \\
\text { Private } \\
\text { Spaces }\end{array}$ & $\begin{array}{l}\text { Schools/ } \\
\text { Educational } \\
\text { Institutions }\end{array}$ & Workplaces & $\begin{array}{l}\text { Public } \\
\text { Places }\end{array}$ \\
\hline \hline Exclusion & $77 \%$ & $52 \%$ & $40 \%$ & $3 \%$ & $21 \%$ \\
\hline \hline $\begin{array}{l}\text { Non- } \\
\text { Participation }\end{array}$ & $16 \%$ & $15 \%$ & $5 \%$ & $1 \%$ & $17 \%$ \\
\hline
\end{tabular}

In spaces where exclusion and non-participation were lesser as seen in the table above, structural inequities of exclusion and discrimination showed up in the form of the far more prevalent forms of forced or imbibed practices and shaming. ${ }^{4} 44 \%$ and $45 \%$ of respondents reported shaming in schools/educational institutions and public places, respectively. $55 \%$ and $25 \%$ reported gaslighting and lack of paid menstrual leave in workplaces.

\footnotetext{
${ }^{2}$ International Women's Day-8 March 2019 Women's Menstrual Health Should No Longer Be a Taboo, United Nations Hum. RTs. OfF. OF THE High Comm'R (Mar. 5, 2019), https://www.ohchr.org/EN/NewsEvents/Pages/DisplayNews.aspx?NewsID=24258\&LangID=E [https://perma.cc/4JZE-7LBU].

${ }^{3}$ The survey is limited by its random sampling and sampling size.

${ }^{4}$ Non-Participation: When an individual is not being allowed to participate in a dynamic collective activity (for example, family ceremonies or festivals); Exclusion: When an individual is ostracized/not allowed to enter spaces (for example, put in separate room, made to sit on the floor, made to use different utensils); Practices: When a ritualistic belief is perpetuated (for example, washing hair on third day of menstrual cycle, not touching pickle); Shaming: When one is mocked or belittled for menstruating.
} 
Menstrual discrimination includes forms that propagate social seclusion, medical or surgical suppression, that may cause physical disability and harm, ${ }^{5}$ lack of opportunity, or a limited degree of freedom are all intertwined with the way menstruators' bodies are perceived to be bodies of reproductive function/labor. These exclusions arise by virtue of "deemed impurity" around the bleeding phase of the cycle, invisibilizing the other aspects of menstrual cycle that contribute to reproductive labor ${ }^{6}$ of limited biological agency and choice.

The institutions of family and religion oppressively propagate these forms of exclusion, which pervade other organized and unorganized institutions as well. It is also within the ambit of "health needs," "7 where menstrual health ought to be recognized as a vital sign of health institutionally and is amplified by menstrual exclusionary practices that enjoy cultural and constitutional impunity.

The forms of exclusion ${ }^{8}$ experienced by menstruators in India include the following.

\section{A. Menstrual Exclusion Practices Within Private Spaces and Homes}

Menstrual exclusion practices within the home include the denial of menstruators' rights to pray, cook, clean, touch, or be in the presence of others or, specifically, men in the household, partake in funeral or cremation rituals, religious or ritualistic festivals, access to one's own bed/clothes, or access to facilities meeting minimum Water Sanitation and Hygiene (WASH) standards. Menstruators are also shamed and ridiculed for staining during menstruation and have their cycle tracked or monitored by their families. These practices within the household essentially amount to a practice of

\footnotetext{
${ }^{5}$ Cyclone Gaja: India Girl Segregated During Period Dies, BBC News (Nov. 21, 2018), https://www.bbc.com/news/world-asia-india-46286284 [https://perma.cc/RW7D-QDPP].

${ }^{6}$ This includes the labor of living with menstrual disorders (e.g., premenstrual exacerbation, premenstrual dysphoric disorder, polycystic ovary syndrome, premenstrual syndrome, endometriosis) and labor irrespective of forced, voluntary, or non-exercise of reproductive choice.

${ }^{7}$ Menstrual health was recognized as the sixth vital sign of health by the American College of Obstetricians

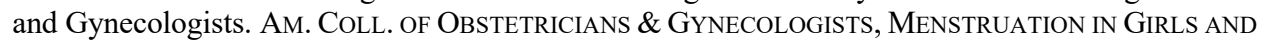
Adolescents: Using the Menstrual CyCle as a Vital Sign (Dec. 2015), https://www.acog.org//media/project/acog/acogorg/clinical/files/committee-opinion/articles/2015/12/menstruation-in-girls-andadolescents-using-the-menstrual-cycle-as-a-vital-sign.pdf [https://perma.cc/A5AF-BPZG].

${ }^{8}$ The exclusions referred to here are part of observations from the aforementioned survey, as well as the organizational learnings and experiences of Boondh working in the menstrual health space.
} 
untouchability. The complex interplay of religion, caste, and gender ${ }^{9}$ further aggravate the way in which menstruators experience menstrual exclusion. ${ }^{10}$

\section{B. Exile through Enforced Menstrual Hut Practices}

A number of communities across India continue to practice banishment, whereby menstruators are placed in enforced isolation to huts or rooms outside the main house during their periods. ${ }^{11}$ These huts normally have very basic amenities. Enforced menstrual hut practices are linked to impacts on the physical safety and health of menstruators, as they are vulnerable to sexual assault, natural calamities, and animal attacks, and have access to limited WASH facilities, nutrition, exercise, and education during their periods.

\section{Exclusion from Places of Worship}

Forms of exclusion from places of worship include restrictions on access to temples, mosques, churches, and other institutions, ${ }^{12}$ but also family gatherings at wedding halls, party halls, homes, and cremation grounds. ${ }^{13}$ This exclusion affects menstruators' psychosocial health, right to exercise choice, right to freely practice their religion and self-determination, and other rights.

\footnotetext{
${ }^{9}$ For example, the Malayalam movie "The Great Indian Kitchen" indicts menstrual exclusion with dimensional nuance; at one point, the protagonist is stripped of even a mattress to lay on as her menstruating body is considered impure. See The Great Indian Kitchen (Cinema Cooks, Mankind Cinemas, Symmetry Cinemas 2021).

${ }^{10}$ See Deepthi Sukumar, Personal Narrative: Caste is my Period, in Palgrave Handbook of Critical Menstruation Studies 137, 137-41 (Chris Bobel et al. eds., 2020).

${ }^{11}$ Deepshikha Sharma, Menstrual Hut: Quarantines for Impurity, FEMINISM IN INDIA (May 18, 2020), https://feminisminindia.com/2020/05/18/menstrual-huts-quarantines-impurity/ [https://perma.cc/NMA2M2HM]; Puja Changoiwala, The 'Period Huts' of India, Juggernaut (Apr. 8, 2019), https://www.jgnt.co/period-huts-of-india [https://perma.cc/BME6-LWJS].

${ }^{12}$ Aru Bhartiya, Mentruation, Religion and Society, 3 InT’L J. ScI. \& HumAn. 523, 523-24 (2013).

${ }^{13}$ Ilana Cohen, Menstruation and Religion: Developing a Critical Menstrual Studies Approach, in PALgRAVE Handbook of Critical Menstruation Studies 115, 117-22 (Chris Bobel et al. eds., 2020).
} 


\section{Menstrual Exclusion Practices at Educational Institutions and Workplaces}

Women working as sugarcane cutters in the Beed district, Maharashtra have reported forced hysterectomies, which are pushed on them by employers to ensure that they are still able to work during their periods. News reports also indicate that doctors in the district have attempted to pass off menstrual bleeding as a symptom of cancer to convince women to undergo hysterectomies. ${ }^{14}$ Some hostels in schools and universities have also come under scrutiny for forcing students to disclose their menstrual cycles, sometimes even going so far as to strip search them to force compliance and then banishing them from the main hostel premises to dingy rooms or restricting their access to dining halls, kitchens, and prayer rooms during their periods. ${ }^{15}$

\section{Constitutional Challenges to Menstrual Exclusion Practices}

\section{A. The Sabarimala Judgment}

In Indian Young Lawyers Association v. State of Kerala ${ }^{16}$ (widely referred to as the Sabarimala judgment), the Indian Supreme Court issued a landmark decision in a case involving a constitutional challenge to rules issued by the Kerala government that permitted restriction of the entry of women into places of public worship if "custom and usage" disallowed their entry. These rules were used to justify the ban on entry into the Sabarimala temple of women aged between ten and fifty, based on a tradition prohibiting the entry of menstruating women.

In a 4:1 majority issued in 2018, a five-judge bench of the Supreme Court found that the ban on entry of women of menstruating age into the Sabarimala temple violated women's right to practice religion as well as the right to non-discrimination on the basis of sex under Articles 25 and 15 of the Indian Constitution. The dissenting judge, Justice Malhotra (the sole woman on the bench), held that the right to equality does not override

\footnotetext{
${ }^{14}$ Shruti Ganapatye, Beed Women Demand Justice for Lost Wombs, Mumbai Mirror (June 13, 2019), https://mumbaimirror.indiatimes.com/mumbai/civic/beed-women-demand-justice-for-lostwombs/articleshow/69763249.cms [https://perma.cc/QF22-MMYC].

${ }^{15}$ Express News Service, Gujarat: 66 Bhuj College Students Made to Strip for Menstrual Check, Principal Booked, INDIAN EXPRESS (Feb. 15, 2020), https://indianexpress.com/article/india/bhuj-colg-students-made-tostrip-menstrual-check-6268916/ [https://perma.cc/82JM-27DR].

${ }^{16}$ (2019) 11 SCC 1 (India).
} 
the fundamental right to religious freedom, and hence the temple authorities had the right to restrict the entry of women to uphold their essential religious practice.

Surprisingly, aside from the concurring opinion of Justice Chandrachud, the focus of the remaining judges was largely on the issue of religious freedom, as well as establishing whether the right of women to freely practice their religion was violated by the temple entry ban. However, as recognized by Justice Chandrachud, the real issue in Sabarimala was about the "freedom from societal oppression, which comes from a stigmatized understanding of menstruation." ${ }^{17}$ Expanding on this theme, Justice Chandrachud's ruling is premised on three main grounds that lay a solid foundation for further constitutional challenges to menstrual exclusion practices. First, that the menstrual status of a woman is "an intrinsic part of her privacy" and that the Constitution must not allow any exclusion to be practiced or denial perpetrated on this basis. Second, that imposing "exclusionary disabilities" on women based on their menstrual status through social and religious practices violates the constitutional right to dignity. Third, that the prevalent menstrual taboos are based on notions of impurity and pollution, which result in "systemic humiliation, exclusion and subjugation" of women and have "no place in a constitutional regime." Based on this reasoning, Justice Chandrachud held that the social exclusion of women, based on menstrual status, is a form of untouchability prohibited by Article 17 of the Constitution.

\section{B. Applying the Sabarimala Ruling to Other Menstrual Exclusion Practices and the Horizontal Application of Fundamental Rights}

The groundbreaking decision in Sabarimala has the potential to be widely applied to support successful constitutional challenges to other menstrual exclusion practices described above. However, there remain a few serious obstacles to the applicability of the Sabarimala ruling in these spheres. The constitutional challenge in Sabarimala was to a statutory rule passed by the government to uphold restricted entry to temples. This is not the case for most other menstrual exclusion practices, which are enforced by private actors in private and public spaces.

There are numerous instances of Indian courts applying fundamental rights horizontally against private actors, though the jurisprudence on the extent and

${ }^{17} I d$. at 216 (per Chandrachud, J., concurring). 
circumstances in which such horizontal application can take place is not very clear. ${ }^{18}$ However, there are three potential ways in which the menstrual exclusion practiced in the private sphere can be constitutionally challenged under Indian law.

\section{Right to Non-Discrimination Under Article 15(2)}

Article 15(2) has direct horizontal application as it prohibits discrimination on the basis of sex, among other grounds, in access to public places including shops, public restaurants, hotels, and other places dedicated to the use of the general public, such as wells, tanks, or roads, even when such discrimination is practiced by private entities. ${ }^{19}$ The term "shops" in Article 15(2) is used as a "generic term" to cover places providing services to the public, ${ }^{20}$ and it has been applied by the Supreme Court to include private educational institutions. ${ }^{21}$

In the Sabarimala case, the concurring opinion of at least one judge found a violation of Article 15 by the state, as the ban on entry of women of menstruating age into the temple based on biological ground of menstruation "discriminates against women on the basis of their sex only." ${ }^{, 2}$ However, this finding was based on a violation of clause (1) of Article 15, which deals with non-discrimination by the state. Though Justice Chandrachud also relied on Article 15(2) as one of the bases on which the guarantee against social exclusion emanates, Justice Malhotra, in her dissenting opinion, convincingly reasoned that places of religious worship are excluded from the ambit of Article 15(2). Justice Malhotra's reasoning for the exclusion of places of religious worship from the ambit of Article 15(2) is based not only on the wording of the text, but

\footnotetext{
${ }^{18}$ Gautam Bhatia, Horizontality Under the Indian Constitution: A Schema, InDIAN Const. L. \& PhIL. (May 24, 2015), https://indconlawphil.wordpress.com/2015/05/24/horizontality-under-the-indian-constitution-aschema/ [https://perma.cc/WJC3-PQAK].

${ }^{19}$ Gautam Bhatia, Horizontal Discrimination and Article 15(2) of the Indian Constitution: A Transformative Approach, 11 Asian J. COMPAR. L. 87, 108 (2016).

${ }^{20}$ See line 7.62 .126 of Constituent Assembly of India Debates (Proceedings) - Volume VII, CONST. OF INDIA (Nov. 18, 1948), https://www.constitutionofindia.net/constitution_assembly_debates/volume/7/1948-11-29 [https://perma.cc/EBL6-6T5S].

${ }^{21}$ Indian Medical Association v. Union of India, (2011) 7 SCC 179 (India).

${ }^{22}$ Indian Young Lawyers Association v. State of Kerala, (2019) 11 SCC 1, 150 (per Nariman, J., concurring) (India). Justice Chandrachud also found a violation of Article 15, though under Article 15(2) as opposed to $15(1)$.
} 
also on the intentions of the framers derived from the Constituent Assembly debates. ${ }^{23}$ Given this, it remains highly debatable whether courts will rely on Article 15(2) alone to overturn entry bans to places of religious worship for menstruating women. However, given the otherwise wide ambit of Article 15(2), menstrual exclusion practices in schools and hostels could potentially be challenged under this provision.

\section{Prohibition of Untouchability Under Article $\mathbf{1 7}$}

Article 17 of the Indian Constitution abolishes untouchability and forbids its practice "in any form." Similar to Article 15(2), the fundamental right against untouchability is intended to be enforceable against not only the state, but also individuals and other private parties. Article 17 has been traditionally interpreted to refer to caste-based untouchability only. However, Justice Chandrachud, in his opinion in Sabarimala, highlighted the decision of the framers of the Constitution to leave the term "untouchability" undefined and to add the words "in any form," which were not present in earlier drafts, to ensure that all forms of the practice were covered (irrespective of religion). Noting that Article 17 was reflective of the transformative ideal of the Constitution, he concluded that it would cover "every manifestation of untouchability," including the social exclusion of women based on menstrual status, which is rooted in similar notions of purity and pollution as caste-based untouchability. ${ }^{24}$

This expansive reading of the prohibition of untouchability to cover practices of menstrual exclusion has a far-reaching impact. Article 17 also requires the enforcement of any disability arising out of untouchability to be an offense punishable by law, giving rise to a constitutional obligation on the state to take necessary steps to interdict such violations and protect the fundamental right of individuals against untouchability. ${ }^{25}$ As such, applying Justice Chandrachud's interpretation of untouchability, the Indian government has a constitutional obligation to pass laws prohibiting forms of menstrual exclusion which amount to untouchability. For instance, the Protection of Civil Rights Act (1955) prohibits enforcing numerous disabilities on the grounds of untouchability, particularly religious disabilities (e.g., restricting entry to any place of public worship), social disabilities (including with regard to employment, the use of public rest houses, and the observance of social or religious customs or ceremonies) and the refusal of

\footnotetext{
${ }^{23}$ See Suhrith Parthasarathy, An Equal Right to Freedom of Religion: A Reading of the Supreme Court's Judgment in Sabarimala, 3 UnIV. OXFord Hum. RTs. Hub J. 123, 142 (2020).

${ }^{24}$ Indian Young Lawyers Association v. State of Kerala, (2019) 11 SCC 1, 212 (per Chandrachud, J., concurring) (India).

${ }^{25}$ People's Union for Democratic Rights v. Union of India, (1983) 3 SCC 235 (India).
} 
admission to hospitals, educational institutions, and hostels. As such, similar restrictions should apply to menstrual exclusion practices, which amount to untouchability as well.

\section{Imposing a Positive Obligation on the State to Protect Fundamental Rights by Regulating Private Actors}

In addition to applying constitutional provisions which are directly enforceable against private actors, Indian courts have often imposed positive obligations on states to prevent or address the violation of fundamental rights, even where such violation is by private actors. The most famous example is the Vishaka case, where the Supreme Court held that the government's failure to pass legislation on sexual harassment was a violation of the fundamental rights of women as the state had failed to meet its positive obligation to protect citizens from sexual harassment. ${ }^{26}$ A similar principle was applied by the Bombay High Court in Noorjehan Safia Niaz v. State of Maharashtra, ${ }^{27}$ where a constitutional challenge was raised to the ban on entry of women to the inner sanctum of the Haji Ali Dargah. The ban in this case was justified on various grounds, including that menstruating women "were unclean and impure in Islam." The High Court found a violation of the right to equality under Articles 14 and 15 and held that the State had a duty to ensure the protection of the fundamental rights of its citizens and to ensure that there is no gender discrimination, even by the trust which managed the mosque (though it was not an entity of the state). ${ }^{28}$

The Nepal Supreme Court has also imposed similar positive obligations on the Nepali government to curb the practice of chhaupadi (exile of women to menstrual huts). In Dil Bahadur Bishwokarma v. Prime Minister, ${ }^{29}$ the court declared the practice of chhaupadi to be discriminatory against women and issued a directive to the government to educate people on the harmful effects of the practice, as well as to pass a comprehensive law to eradicate customary practices like chhaupadi, which are detrimental to the health of women. ${ }^{30}$

\footnotetext{
${ }^{26}$ Vishaka v. State of Rajasthan, (1997) 6 SCC 241 (India).

27 (2016) 5 AIR Bom R 660 (India).

${ }^{28}$ Id. at 6, 13; see also Devershi Mishra \& Komal Khare, Haji Ali Judgment: Assessing Indirect Horizontality and Traversing beyond Essential Practices Doctrine to an Individual Centric Approach, 2 ELEN. L. ReV. 73 (2016).

${ }^{29}$ Writ Petition No. 061-3303, Decision of the Supreme Court (May 1, 2004) (Nepal).

${ }^{30}$ Raju Prasad Chagai, Judicial Response to Reproductive Rights: Experience of Public Interest Litigation in Nepal, J. Health Stud. 24, 40 (2008).
} 
Thus, there is ample scope for Indian courts to issue similar directives imposing an obligation on the government to protect women from menstrual exclusion practices, particularly exile to menstrual huts.

\section{CONCLUSION}

The Indian Constitution, and particularly the constitutional right against untouchability, provides a framework for "radical social transformation." 31 The decision of the Supreme Court in Sabarimala adopts such a transformative approach and was expected to pave the way for radical change. However, reality has not matched expectations. There were large-scale public protests against the judgment in many parts of the country. Only two women have successfully managed to enter the temple postjudgment, overcoming monumental odds including violence, physical resistance to their entry, and death threats. ${ }^{32}$

In light of the pushback against the decision, the Supreme Court itself has agreed to review its own decision. The case has now been referred to a nine-judge bench of the Court to decide on the larger question of the balance between the right to religious freedom and other fundamental rights, putting the original Sabarimala verdict in jeopardy. It remains to be seen whether Indian courts will continue to expansively interpret constitutional rights and move forward to uphold the right of women against other forms of menstrual exclusion as well, or whether even the gains made in Sabarimala will be lost in the face of public anger and religious conservatism.

\footnotetext{
${ }^{31}$ Indian Young Lawyers Association v. State of Kerala, (2019) 11 SCC 1, 201 (per Chandrachud, J., concurring) (India).

${ }^{32}$ Sneha Mary Koshy, Two Women Below Fifty Enter Sabarimala: Temple Reopens After "Purification", NDTV (Jan. 3, 2019), https://www.ndtv.com/india-news/two-women-below-50-enter-keralas-sabarimalatemple-police-sources-1971204 [https://perma.cc/HC7C-TA5G].
} 